\title{
Antimicrobial-Resistant Bacteria in Infected Wounds, Ghana, 2014
}

\section{Hauke Janssen, ${ }^{2}$ Iryna Janssen, ${ }^{2}$ Paul Cooper, Clemens Kainyah, Theresia Pellio, Michael Quintel, Mathieu Monnheimer, Uwe Groß, Marco H. Schulze}

Wound infections are an emerging medical problem worldwide, frequently neglected in under-resourced countries. Bacterial culture and antimicrobial drug resistance testing of infected wounds in patients in a rural hospital in Ghana identified no methicillin-resistant Staphylococcus aureus or carbapenem-resistant Enterobacteriaceae but identified high combined resistance of Enterobacteriaceae against third-generation cephalosporins and fluoroquinolones.

$\mathrm{B}$ acteriologic investigation of clinical specimens is an essential tool for active surveillance of antimicrobial drug resistance. Knowledge of causative bacterial species and their resistance profile enables targeted antimicrobial therapy, limits ineffective antimicrobial therapy, and avoids in part unnecessary antimicrobial pressure to noninvolved bacterial pathogens (1). Available antimicrobial resistance data will sensitize clinicians and policy makers and are a prerequisite for updating national treatment guidelines $(1,2)$. These data contribute to prevention and control of antimicrobial drug resistance (1).

Wound infections are an emerging medical problem worldwide; the economic burden and morbidity and mortality rates are huge $(3,4)$. Because of the frequent polymicrobial nature of infected wounds, bacteriologic investigations are demanding and frequently neglected in sub-Saharan Africa countries (5).

\section{The Study}

Since 2000, the Institute for Medical Microbiology of the University Medical Center Goettingen, Goettingen, Germany, has assisted the running of the bacteriology laboratory in St. Martin de Porres Hospital in Eikwe, Ghana (2). Eikwe is a rural coastal village in the Western Region of Ghana; its mission hospital has an admission capacity of $\approx 200$ beds and serves $\approx 380,000$ persons.

Author affiliations: University Medical Center Goettingen,

Goettingen, Germany (H. Janssen, I. Janssen, M. Quintel,

M. Monnheimer, U. Groß, M.H. Schulze); St. Martin de Porres

Hospital, Eikwe, Ghana (P. Cooper, C. Kainyah, T. Pellio)
During March-July 2014, we conducted a prospective study at St. Martin de Porres Hospital, performing bacteriologic investigations of infected wounds of inpatients and outpatients during routine working hours (Monday-Friday, 8 AM-4 PM). The hospital administration (the local ethics review panel) authorized the study. Patients from whom wound swab samples were investigated provided consent to be included in the study.

Medical doctors diagnosed wound infections clinically, according to the classic signs of inflammation. After wounds were carefully cleaned with sterile gauze moistened with a sterile solution of $0.9 \%$ sodium chloride, samples were collected from the wound ground and edge on sterile cotton swabs and immediately transported to the bacteriology laboratory in Amies transport medium (Copan, Brescia, Italy). The samples were inoculated onto MacConkey agar and 7\% sheep blood agar (Tulip Diagnostics, Goa, India) and thereafter incubated aerobically at $35^{\circ} \mathrm{C}$. Both plates were read after 24 and 48 hours. Gram staining was performed to ensure wound specimen quality and to check for bacteria, neutrophils, and epithelial cells.

Bacterial isolates were initially identified (to genus level) by colony morphology, Gram staining, catalase reaction, oxidase reaction, coagulase reaction, indole reaction, and growth on Kligler iron agar, as described by Cheesbrough (6). Bacterial isolates were stored in microbanks at $-20^{\circ} \mathrm{C}$. Species identification was completed (to species level) at the Institute for Medical Microbiology in Goettingen, Germany, by using MALDI Biotyper 3.0 (Bruker Daltonics, Bremen, Germany).

According to locally available resources, antimicrobial resistance testing was performed through disk diffusion, which guided the treatment of the wound infections. Antimicrobial resistance testing was repeated with VITEK 2 (bioMérieux, Marcy-l'Étoile, France) at the Institute for Medical Microbiology by using AST-P632, AST-P586, AST-N214, and AST-N248 cards with respect to bacterial species and according to the breakpoint tables for interpretation

\footnotetext{
${ }^{1}$ Preliminary results from this study were presented at the Annual Meeting of the German Society of Tropical Medicine and International Health; October 7-8, 2016; Bonn, Germany; and at the 69th Annual Meeting of the German Society for Hygiene and Microbiology; March 5-8, 2017; Wuerzburg, Germany.
}

${ }^{2}$ These authors contributed equally to this article. 
of MICs in EUCAST version 4.0 (7). Quality control was performed with the reference strains Pseudomonas aeruginosa ATCC 27853, Escherichia coli ATCC 25922, and Staphylococcus aureus ATCC 29213.

Of the 67 wound swab samples, 39 (58.2\%) were from female patients. The mean age of the 67 patients was 40.1 \pm 20.8 years (range $1-90$ years, median 39 years). Of the 67 samples, collection sites were upper extremity for $4(6.0 \%)$, trunk/head for 15 (22.4\%), lower extremity for 39 (58.2\%), and laparotomy site for 9 (13.4\%) (online Technical Appendix, https://wwwnc.cdc.gov/EID/article/24/5/17-1506Techapp1.pdf). A hospital-acquired wound infection was diagnosed for $21(31.3 \%)$ patients.

All investigated wound swab samples grew bacterial pathogens. Overall, 32 species of bacteria were isolated; median was 3 (range 1-7) species/specimen. Of the 189 isolated species, 72 (38.1\%) were Enterobacteriaceae, 69 (36.5\%) were gram positive, and 48 (25.4\%) were nonfermenters (online Technical Appendix Table 2). Of the 67 samples, infection was monomicrobial in $17(25.4 \%)$ and polymicrobial in $50(74.6 \%)$. The most frequently detected bacterium in monomicrobial and polymicrobial infections was $S$. aureus. The predominant bacteria in polymicrobial infections were Enterobacteriaceae and nonfermenters (online Technical Appendix Table 3). Results of VITEK 2 antimicrobial resistance testing of the most frequently found bacterial species are shown in Table 1.
The spectrum of isolated bacteria is comparable to that reported by other studies from sub-Saharan Africa countries, such as Nigeria (9), Tanzania (3), and Rwanda (10). Frequently, studies describe detected pathogens at the genus level only $(3,10)$. Concerning the proportion of grampositive to gram-negative pathogens, we isolated slightly more gram-positive pathogens than others (3,9-11).

One of the most common bacteria found in wound infections is $S$. aureus $(3,5,10-12)$, which was most frequently identified in our study (online Technical Appendix Table 2); however, we detected no methicillin-resistant $S$. aureus (MRSA). In contrast, studies from urban areas in sub-Saharan Africa countries found MRSA rates of $>80 \%$ $(10,12)$. Urban areas are centers of specialized healthcare, where many patients who may already have a long medical history are referred. Such referrals predispose urban patients, staff, and others to more MRSA colonization and infection than experienced by those in rural areas (13). The hospital in Eikwe is a general hospital; the villagers are mainly fishermen, and there are no big animal farms in the area. Predisposition to MRSA in this area may be low.

We found no carbapenem resistance in Enterobacteriaceae (Table 1). Of great concern were the high rates of resistance of E. coli, Klebsiella pneumoniae, and Enterobacter cloacae complex against third-generation cephalosporins, fluoroquinolones, or both (Table 2), as have been found in other studies from urban areas $(3,5,10)$. The

\begin{tabular}{|c|c|c|c|c|c|c|c|c|}
\hline \multirow[b]{2}{*}{ Drug } & \multicolumn{8}{|c|}{$\%$ Resistant } \\
\hline & $\begin{array}{l}\text { Staphylococcus } \\
\text { aureus, } \mathrm{n}=31\end{array}$ & $\begin{array}{c}\text { Enterococcus } \\
\text { faecalis, } \\
\mathrm{n}=21\end{array}$ & $\begin{array}{c}\text { Proteus } \\
\text { mirabilis, } \\
\mathrm{n}=20\end{array}$ & $\begin{array}{l}\text { Escherichia } \\
\text { coli, } \mathrm{n}=19\end{array}$ & $\begin{array}{c}\text { Klebsiella } \\
\text { pneumoniae, } \\
\mathrm{n}=13\end{array}$ & $\begin{array}{c}\text { Enterobacter } \\
\text { cloacae } \\
\text { complex, } \mathrm{n}=10\end{array}$ & $\begin{array}{c}\text { Pseudomonas } \\
\text { aeruginosa, } \\
n=20\end{array}$ & $\begin{array}{c}\text { Acinetobacter } \\
\text { baumannii } \\
\text { complex, } \mathrm{n}=8\end{array}$ \\
\hline PEN & 93.5 & & & & & & & \\
\hline AMP & & 0 & 70.0 & 94.7 & 100 & 100 & & \\
\hline OXA & 0 & & & & & & & \\
\hline SAM & & 0 & 45.0 & 82.2 & 69.2 & 100 & & \\
\hline TZP & & & 0 & 10.5 & 46.2 & 30.0 & 10.0 & \\
\hline CXM & & & 5.0 & 57.9 & 46.2 & 80.0 & & \\
\hline CTX & & & 5.0 & 47.4 & 46.2 & 40.0 & & \\
\hline CAZ & & & 5.0 & 47.4 & 46.2 & 40.0 & 5.0 & $37.5 \dagger$ \\
\hline IPM & & & & & & & 0 & 0 \\
\hline MEM & & & 0 & 0 & 0 & 0 & 5.0 & 0 \\
\hline ERY & 3.2 & 100 & & & & & & \\
\hline CLI & 3.2 & 100 & & & & & & \\
\hline TET & 67.7 & 100 & & & & & & \\
\hline GEN & 3.2 & & 15.0 & 46.2 & 46.2 & 40.0 & 10.0 & 62.5 \\
\hline AMI & & & & & & & 0 & 0 \\
\hline CIP & & & 20.0 & 46.2 & 46.2 & 30.0 & 15.0 & 37.5 \\
\hline LVX & 0 & & & & & & & \\
\hline SXT & 32.3 & 100 & 75.0 & 69.2 & 69.2 & 50.0 & & \\
\hline FOF & 0 & & & & & & & \\
\hline RIF & 0 & & & & & & & \\
\hline VAN & 0 & 0 & & & & & & \\
\hline $\begin{array}{l}{ }^{*} \text { Antim } \\
\text { interpr } \\
\text { ciproflc } \\
\text { levoflo } \\
\text { tetracy }\end{array}$ & $\begin{array}{l}\text { ial susceptibility te } \\
\text { n of MICs, version } \\
\text { A; CLI, clindamycin } \\
\text {; MEM, meropene } \\
\text { TZP, piperacillin/t } \\
\text { etation of the CAZ } \\
\text { standards for an }\end{array}$ & $\begin{array}{l}\text { ting was perform } \\
4.0,2014 \text { (7). Bla } \\
\text {; CTX, cefotaxime } \\
\text { n; OXA, oxacillin; } \\
\text { azobactam; VAN, } \\
\text { MIC for A. baum } \\
\text { imicrobial suscept }\end{array}$ & $\begin{array}{l}\text { with VITEK } \\
\text { cells indice } \\
\text { CXM, cefurc } \\
\text { EN, penicilli } \\
\text { ancomycin. }\end{array}$ & $\begin{array}{l}2 \text { (bioMérieux } \\
\text { ate no testing p } \\
\text { oxime; ERY, er } \\
\text { n; RIF, rifampir } \\
\text { followed the re } \\
\text { (8). }\end{array}$ & $\begin{array}{l}\text { arcy-l'Étoile, F } \\
\text { ormed. AMI, a } \\
\text { romycin; FOF } \\
\text { AM, ampicillir }\end{array}$ & $\begin{array}{l}\text { nce) according to } \\
\text { kacin; AMP, ampi } \\
\text { sfomycin; GEN, g } \\
\text { ulbactam; SXT, tri }\end{array}$ & $\begin{array}{l}\text { e EUCAST break } \\
\text { lin; CAZ, ceftazidi } \\
\text { tamicin; IPM, imi } \\
\text { ethoprim/sulfame }\end{array}$ & $\begin{array}{l}\text { int tables for } \\
\text { e; CIP, } \\
\text { nem; LVX, } \\
\text { oxazole; TET, }\end{array}$ \\
\hline
\end{tabular}


Table 2. Ratio of percentages of antimicrobial drug resistance against third-generation cephalosporin CTX and the fluoroquinolone CIP in selected Enterobacteriaceae isolated from wound infections, Ghana, 2014*

\begin{tabular}{lcccc}
\hline & \multicolumn{3}{c}{$\%$ Resistant } \\
\cline { 2 - 5 } Drug resistance & Proteus mirabilis, $\mathrm{n}=20$ & Eshcerichia coli, $\mathrm{n}=19$ & $\begin{array}{c}\text { Klebsiella pneumoniae, } \\
\mathrm{n}=13\end{array}$ & $\begin{array}{c}\text { Enterobacter cloacae } \\
\text { complex, } \mathrm{n}=10\end{array}$ \\
\hline CTX-S + CIP-S & 80.0 & 42.1 & 53.8 & 60.0 \\
CTX-S + CIP-R & 15.0 & 10.5 & $\mathrm{ND}$ & $\mathrm{ND}$ \\
CTX-R + CIP-S & $\mathrm{ND}$ & 5.3 & $\mathrm{ND}$ & 10.0 \\
CTX-R + CIP-R & 5.0 & 42.1 & 46.2 & 30.0 \\
\hline${ }^{*}$ Antimicrobial susceptibility testing was performed by using VITEK 2 (bioMérieux, Marcy-l'Étoile, France) according to the EUCAST breakpoint tables for
\end{tabular}
interpretation of MICs, version 4.0, 2014 (7). CIP, ciprofloxacin; CTX, cefotaxime; ND, not detected; R, resistant; S, susceptible.

indiscriminate use of antimicrobial drugs contributes to this factor (14). Officially, selling antibiotics without prescription is not allowed in Ghana; however, almost every oral antimicrobial drug is available over the counter without any prescription. Eikwe is no exception, although the spectrum of available antimicrobial drugs may be smaller there than in cities. Development of antimicrobial drug resistance may also be enhanced by circulation of counterfeit drugs (15).

Resistance of E. coli and $K$. pneumoniae against thirdgeneration cephalosporins probably occurs through production of extended spectrum $\beta$-lactamase; in E. cloacae complex, it is probably through AmpC- $\beta$-lactamase. However, this statement is only an assumption because we did not perform molecular analyses.

In Eikwe, rain falls throughout the year and humidity is almost constant at $70 \%-90 \%$ despite 2 rainfall peaks (May-June and October-November). The effect of seasonality on the incidence of wound infections and the frequency of infection with gram-negative bacteria may not be so pronounced as that found in other studies from subSaharan Africa countries with high variations in humidity (9). However, because we analyzed only swab samples collected during March-July, the effect of seasonality is difficult to evaluate.

\section{Conclusions}

Antimicrobial drug resistance among gram-negative organisms seems to be widespread in Ghana, even among community-onset infections in rural, resource-limited settings, although MRSA was surprisingly absent. Future research efforts should focus on the transmission dynamics and prevention of gram-negative antimicrobial resistance in those settings. Microbiological investigation of the worldwide problem of wound infections should be encouraged in areas of limited resources and might provide a valuable contribution to the surveillance of increasing antimicrobial resistance, especially in Enterobacteriaceae, and for the treatment of affected patients.

\section{Acknowledgments}

We thank the patients in Ghana for their participation in this study. We also thank the staff from St. Martin de Porres Hospital and the staff from the Institute for Medical Microbiology of the University Medical Center Goettingen for their commitment to perform the study.

\section{About the Author}

Dr. Janssen is an anesthesiologist who during the study worked as a volunteer at St. Martin de Porres Hospital. He supported the medical personnel in the operating theater and trained them in anesthesiology, resuscitation, and general medicine.

\section{References}

1. Vernet G, Mary C, Altmann DM, Doumbo O, Morpeth S, Bhutta ZA, et al. Surveillance for antimicrobial drug resistance in under-resourced countries. Emerg Infect Dis. 2014;20:434-41. http://dx.doi.org/10.3201/EID2003.121157

2. Groß U, Amuzu SK, de Ciman R, Kassimova I, Gross L, Rabsch W, et al. Bacteremia and antimicrobial drug resistance over time, Ghana. Emerg Infect Dis. 2011;17:1879-82. http://dx.doi.org/10.3201/edi1710.110327

3. Kumburu HH, Sonda T, Mmbaga BT, Alifrangis M, Lund O, Kibiki G, et al. Patterns of infections, aetiological agents and antimicrobial resistance at a tertiary care hospital in northern Tanzania. Trop Med Int Health. 2017;22:454-64. http://dx.doi.org/10.1111/tmi.12836

4. Sen CK, Gordillo GM, Roy S, Kirsner R, Lambert L, Hunt TK, et al. Human skin wounds: a major and snowballing threat to public health and the economy. Wound Repair Regen. 2009;17:763-71. http://dx.doi.org/10.1111/j.1524-475X.2009.00543.x

5. Leopold SJ, van Leth F, Tarekegn H, Schultsz C. Antimicrobial drug resistance among clinically relevant bacterial isolates in sub-Saharan Africa: a systematic review. J Antimicrob Chemother. 2014;69:2337-53. http://dx.doi.org/10.1093/jac/dku176

6. Cheesbrough M. District laboratory practice in tropical countries. Part 2. 2nd ed. Cambridge (UK): Cambridge University Press; 2006.

7. The European Committee on Antimicrobial Susceptibility Testing. Breakpoint tables for interpretation of MICs and zone diameters. Version 4.0. 2014 [cited 2017 Sep 9]. http://www.eucast.org/ fileadmin/src/media/PDFs/EUCAST_files/Breakpoint_tables/ Breakpoint_table_v_4.0.pdf

8. Clinical and Laboratory Standards Institute. Performance standards for antimicrobial susceptibility testing: twenty-fourth informational supplement (M100-S24). Wayne (PA): The Institute; 2014.

9. Nwankwo E, Edino S. Seasonal variation and risk factors associated with surgical site infection rate in Kano, Nigeria. Turk J Med Sci. 2014;44:674-80. http://dx.doi.org/10.3906/sag-1305-47

10. Ntirenganya C, Manzi O, Muvunyi CM, Ogbuagu O. High prevalence of antimicrobial resistance among common bacterial isolates in a tertiary healthcare facility in Rwanda. Am J Trop Med Hyg. 2015;92:865-70. http://dx.doi.org/10.4269/ajtmh.14-0607 
11. Manyahi J, Matee MI, Majigo M, Moyo S, Mshana SE, Lyamuya EF. Predominance of multi-drug resistant bacterial pathogens causing surgical site infections in Muhimbili National Hospital, Tanzania. BMC Res Notes. 2014;7:500. http://dx.doi.org/ 10.1186/1756-0500-7-500

12. Mengesha RE, Kasa BG, Saravanan M, Berhe DF, Wasihun AG. Aerobic bacteria in post surgical wound infections and pattern of their antimicrobial susceptibility in Ayder Teaching and Referral Hospital, Mekelle, Ethiopia. BMC Res Notes. 2014;7:575. http://dx.doi.org/10.1186/1756-0500-7-575

13. Falagas ME, Karageorgopoulos DE, Leptidis J, Korbila IP. MRSA in Africa: filling the global map of antimicrobial resistance. PLoS One. 2013;8:e68024. http://dx.doi.org/10.1371/journal.pone.0068024
14. Morgan DJ, Okeke IN, Laxminarayan R, Perencevich EN, Weisenberg S. Non-prescription antimicrobial use worldwide: a systematic review. Lancet Infect Dis. 2011;11:692-701. http://dx.doi.org/10.1016/S1473-3099(11)70054-8

15. Elder DP, Kuentz M, Holm R. Antibiotic resistance: the need for a global strategy. J Pharm Sci. 2016;105:2278-87. http://dx.doi.org/10.1016/j.xphs.2016.06.002

Address for correspondence: Marco H. Schulze, University Medical Center Goettingen, Institute for Medical Microbiology and Goettingen International Health Network, Kreuzbergring 57, D-37075 Goettingen, Germany; email: schulze.marco@med.uni-goettingen.de

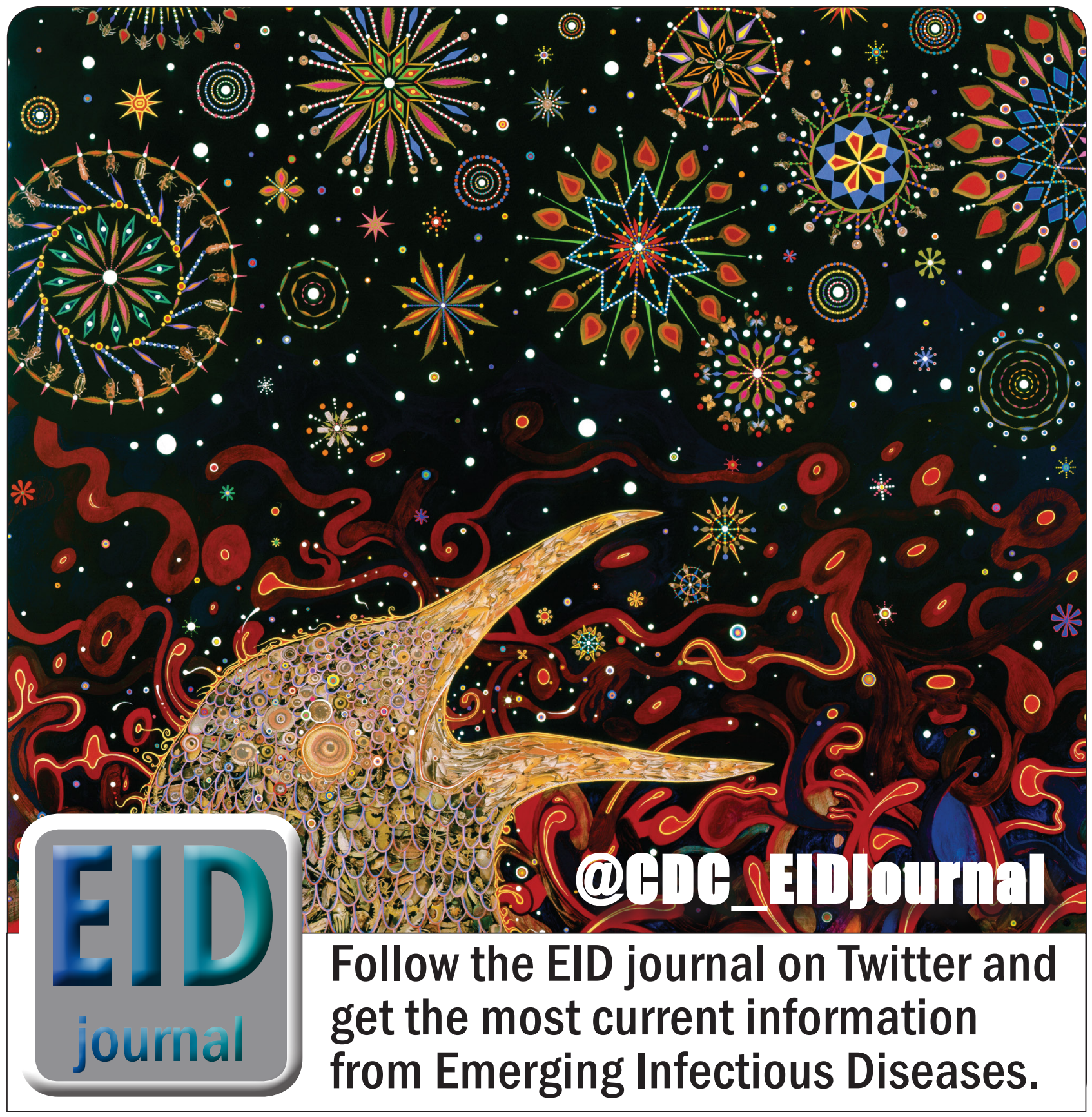

